\title{
PARATEXTUAL MANIFESTATIONS
}

